\title{
Light intensity and type of container on producing Cassia grandis L. f. seedlings
}

\author{
Caio C. P. Leal ${ }^{1}$, Salvador B. Torres ${ }^{2}$, Rômulo M. O. de Freitas ${ }^{3}$, Narjara W. Nogueira ${ }^{1}$ \& Raul M. de Farias ${ }^{4}$ \\ ${ }^{1}$ Programa de Pós-Graduação em Fitotecnia/Universidade Federal Rural do Semi-Árido. Mossoró, RN. E-mail: caioleal3@hotmail.com; \\ narjarawalessa@yahoo.com.br \\ ${ }^{2}$ Departamento de Ciências Vegetais/Universidade Federal Rural do Semi-Árido. Mossoró, RN. E-mail: sbtorres@ufersa.edu.br (Autor correspondente) \\ ${ }^{3}$ Instituto Federal de Educação, Ciência e Tecnologia Baiano. Valencia, BA. E-mail: romulomagno_23@hotmail.com \\ ${ }^{4}$ RM Agrícola/Biolchim do Brasil Imp. e Com. Ltda. São Paulo, SP. E-mail: raul-farias@hotmail.com
}

\section{Key words:}

pink shower cassia

forest species

forest species seeds

seedling growth

shading

\begin{abstract}
A B S T R A C T
This study aimed to determine the effects of the luminosity and type of container on producing Cassia grandis seedlings. Thus, in a substrate composed by topsoil + wood powder (1:1) the seedlings were grown into plastic tubets containing $0.3 \mathrm{dm}^{3}$ of such substrate, or into plastic pots containing $1.0 \mathrm{dm}^{3}$ of the same substrate, and subjected to 50 and $25 \%$ shading or full sunlight. The assessments were performed every two weeks by measuring plant height and stem diameter, during eight weeks period. At the end of this period, the leaf area, dry mass of shoots and roots, the ratio between height of plant/diameter of stem, and the Dickson quality index were also assessed. The experiment was carried out in a completely randomized design with treatments arranged in a $3 \times 2$ factorial [ 3 luminosity levels (50,25\% shading and full sunlight) x 2 types of containers (plastic tubets and clay pots)] with four replicates of 10 seedlings each. Means were compared by Tukey test at 0.05 probability level and adjustments for the non-linear regression polynomial curves for the assessed characteristics were computed in function of time. Shadings of 25 and $50 \%$ were the best alternatives to luminosity; and the tubets were the most suitable containers for production of Cassia grandis seedlings.
\end{abstract}

\section{Palavras-chave:}

cássia-rosa

espécie florestal sementes de espécies florestais crescimento de mudas sombreamento

\section{Intensidade da luz e do tamanho do recipiente na produção de mudas de Cassia grandis L. f.}

\section{R E S U M O}

Este estudo teve, como objetivo, determinar os efeitos da luminosidade e do tipo de recipiente na produção de mudas de Cassia grandis; para isto foram cultivadas, em um substrato composto por terra vegetal + pó de madeira (1:1), as mudas, em tubete contendo $0,3 \mathrm{dm}^{3}$ deste substrato e em vasos de plástico contendo $1,0 \mathrm{dm}^{3}$ do mesmo substrato as quais foram submetidas aos sombreamentos de 50 e $25 \%$ e pleno sol. As avaliações foram realizadas a cada duas semanas medindo-se a altura das plantas e o diâmetro do caule, durante o período de oito semanas e ao final da oitava semana a área foliar, a massa seca da parte aérea e raiz, a razão entre altura de planta/diâmetro do caule e o índice de qualidade de Dickson, também foram determinados. O experimento foi conduzido em delineamento inteiramente casualizado, com os tratamentos arranjados em esquema fatorial $3 \times 2$ [3 níveis de luminosidade $(50$ e $25 \%$ de sombreamento e sem sombreamento) e dois tipos de containers (tubetes de plástico e vaso de plastico)], com quatro repetições cada uma contendo 10 plantas As médias foram comparadas pelo teste de Tukey em nivel de 0,05 de probabilidade e os ajustes das curvas polinomiais de regressão não linear para as características avaliadas foram calculados em função do tempo; os sombreamentos de 25 e $50 \%$ foram as melhores alternativas de luminosidade e os tubetes foram os recipientes mais adequados para a produção de mudas de Cassia grandis. 


\section{INTRODUCTION}

The floriferous forest species known as Pink Shower (Cassia grandis L. f.) belongs to the family Fabaceae (Caesalpinioideae), and is also commonly known in Brazil as "cassia rosa" (pink cassia), "canafístula", "cassia grande" (big cassia), and "geneúna" (Lorenzi, 2002). This species has been widely used in reforestation projects, recovery of degraded areas and landscaping by its shrubby size, and the beauty and coloration of its flowers. Besides these attributes, this species also has medicinal potential, and its use on fighting various diseases has already been reported in several countries of Central America and South America (Lorenzi 2002; Lodha et al., 2010).

Before its importance, as well as other species with pontential for exploration, there are few studies on propagation of C. grandis. Given this reality, the production of forest seedlings is becoming a very important activity for the recovery of degraded areas, assisting in the recovery of natural balance (Oliveira et al., 2014). One of the factors that explain the considerable increase in the production and sale of seedlings for these purposes is a growing global concern about the quality of the environment (Botelho, 2011). However, one of the most important factors is the choice of the ideal container for production of seedlings of these native species. In this sense, Cunha et al. (2005) state that containers with higher volume of substrate, besides presenting better conditions for the growth of the seedling, is the most suitable for the production of seedlings of slow-growing species, and hence will remain longer in the nursery; or when it is desired to obtain larger seedlings.

Another very important factor that should be considered for the seedling production in nurseries is the light intensity; once light is directly related to photosynthesis (Campos \& Uchida, 2002). Within this context, in studies related to luminosity levels Câmara \& Endres (2008) have stated that the ideal pattern for the initial development of seedlings of exotic forest species must be previously known, since results obtained may be applied to the area to be reforested, before introducing the seedlings of these species.

The response to light intensity on germination of forest species seeds may vary according to the substrate used. This fact has already been proven by Martins et al. (2012) who have achieved significant results for germination of the mangium wattle (Acacia mangium Willd.) seeds when the sowing was performed in a substrate of pinus bark and the seedlings were grown under $30 \%$ shading; as well as when sown in commercial substrate with 30 and 50\% shading. These same authors obtained similar results for germination of black wattle (Acacia mearnsii De Wild.) seeds, when the sowing was performed in a substrate of pine bark and grown under 50\% shading; or in a commercial substrate and grown under full sunlight.
However, by assessing emergence of seeds and initial growth of Tonka bean tree (Dipteryx alata Vogel) seedlings, Mota et al. (2012) have found that 50 or $70 \%$ shading, or even the total sunlight, did not influence the percent emergence of seeds of this plant species. Likewise, Oliveira \& Perez (2012), in evaluating the effect of light on the Trumpet Tree [Tabebuia aurea (Silva Manso) Benth. \& Hook. f. ex S. Moore. seedlings, have verified increases on the phenotypic plasticity for robustness index, as well as to the total dry biomass of seedling; which indicates that the seedlings of this species are suitable for cultivation in nurseries with shading between 30 and $45 \%$.

Given the above, this study aimed to verify the influence of light intensity and container type on producing C. grandis seedlings.

\section{Material ANd Methods}

The study was carried out in a shaded nursery of the Department of Plant Sciences, Federal Rural University of the Semi-Arid (UFERSA), located in the municipality of Mossoró, Rio Grande do Norte, Brazil, over a eight weeks period (September and October, 2012).

The C. grandis seeds were collected from native trees existing in the municipality of "Moreno", Pernambuco State ( $8^{\circ} 07^{\prime} 07^{\prime \prime} \mathrm{S} ; 35^{\circ} 05^{\prime} 32^{\prime \prime} \mathrm{W}$; and $96 \mathrm{~m}$ altitude) during the period extending between October and December, 2011. After collection, the pods were transported to the Laboratory of Seed Analysis, where seeds were extracted with aid of a hammer. Soon after extraction, the seeds were placed to dry in a shaded environment; and then packed into Kraft paper packaging, and stored under controlled environmental conditions of temperature and relative humidity $\left(16^{\circ} \mathrm{C} ; 45 \%\right.$ $\mathrm{RH}$ ), until beginning of experiment. To study development of the C. grandis seedlings, it was used a substrate composed by the mixture of topsoil + wood powder (1:1).

To assess effect of luminosity on development of the $C$. grandis seedlings, the following treatments were used: 1 seedlings grown into plastic tubets, containing $0.3 \mathrm{dm}^{3}$ of the substrate previously described, and kept under 50\% shading; 2 - seedlings grown into plastic pots, containing $1.0 \mathrm{dm}^{3}$ of same substrate, and subjected to shading of 50 and $25 \% ; 3$ - seedlings grown into plastic tubets, containing $0.3 \mathrm{dm}^{3}$ of substrate, and kept under 25\% shading; 4 - seedlings grown into plastic pots, containing $1.0 \mathrm{dm}^{3}$ of substrate, and kept under $25 \%$ shading; 5 - seedlings grown into plastic tubets, containing $0.3 \mathrm{dm}^{3}$ of substrate, and kept at full sun; and 6 - seedlings grown into plastic pots, containing $0.3 \mathrm{dm}^{3}$ of substrate, and kept at full sun. The physical and chemical composition of the substrate used in the experiment is shown on Table 1.

According to recommendations (Bezerra et al., 2012), all the seeds used in this study were submitted to mechanical

Table 1. Physical and chemical composition of a substrate composed by top soil + wood dust substrate used for producing seedlings of Pink Shower Cassia (Cassia grandis L. f.)

\begin{tabular}{|c|c|c|c|c|c|c|c|c|c|c|c|}
\hline SD & TP & $\bar{N}$ & $\mathrm{pH}$ & EC & OM & $\mathbf{P}$ & $\mathrm{K}^{+}$ & $\mathrm{Na}^{+}$ & $\mathrm{Ca}^{2+}$ & $\mathrm{Mg}^{2+}$ & $\mathrm{Al}^{3+}$ \\
\hline $\mathrm{g} \mathrm{cm}^{3}$ & $\%$ & $\mathrm{G} \mathrm{kg}^{-1}$ & water & ds $m^{-1}$ & $g \mathrm{~kg}^{-1}$ & & $\mathrm{mg} \mathrm{dm^{-3 }}$ & & \multicolumn{3}{|c|}{$\mathrm{cmol}_{\mathrm{c}} \mathrm{dm}^{-3}$} \\
\hline 0.44 & 80.33 & 1.12 & 5.18 & 0.20 & 101.39 & 59.43 & 1612.43 & 23.21 & 1.62 & 1.03 & 0.2 \\
\hline
\end{tabular}

SD - Substrate density; TP - Total porosity; N - Nitrogen; EC - Electrical conductivity; OM - Organic matter ; P - Phosphorus; $\mathrm{K}^{+}$- Potassium; Na ${ }^{+}$- Sodium; Ca ${ }^{2+}$ - Calcium; Mg²+ - Magnesium; $\mathrm{Al}^{3+}$ - Aluminum 
scarification and soaked into cold water $\left(28^{\circ} \mathrm{C}\right)$ for $24 \mathrm{~h}$. After such process, a single seed of C. grandis was assigned to each of the containers assessed.

Every 14 days after sowing, the seedling height was measured, with aid of a ruler graduated in centimeters, from the apex to the stem base of each seedling, until they have reached 56 days of age. At each seedling length evaluation, the diameter of stem at ground level was also measured with aid of a digital caliper. At 56 days after sowing the variables: leaf area; dry weight of shoots and roots; ratio between plant height/stem diameter; and Dickson quality index were also evaluated.

For assessing leaf area it was used the software "ImageJ"; which by digital analysis of the leaf surface provides the results directly in $\mathrm{mm}^{2}$.

For determining dry mass of shoots and roots, each plant was sectioned at ground level and aerial parts were separated from the roots. Immediately after, each of these parts was separately packaged into Kraft paper bags and placed to dry at $65{ }^{\circ} \mathrm{C}$ into a drying oven, until reaching constant weight. After drying process, the packages containing dry parts were withdrawn from drying oven, and the dry mass of each of those parts was determined by using an analytical balance with $0.001 \mathrm{~g}$ precision.

Correlation between plant height and stem diameter of the seedlings was determined by the Dickson quality index (DQI) (Dickson et al., 1960), which is obtained by computing the ratio of the total height $(\mathrm{cm}) /$ total diameter $(\mathrm{mm})$ obtained by adding the values found in each replication of each treatment. The DQI of C. grandis seedlings was computed by the following equation: DQI $=$ TDW/[(H/D) + (SDW/RDW $)]$ Where: TDW $=$ total seedling dry weight $(\mathrm{g}) ; \mathrm{H}=$ total height $(\mathrm{cm}) ; \mathrm{D}=$ total stem diameter $(\mathrm{mm})$; SDW = total shoot dry weight $(\mathrm{g})$; RDW $=$ total root dry weight $(\mathrm{g})$.

The experiment was carried out in a completely randomized design with treatments arranged in a $3 \times 2$ factorial [ 3 luminosity levels (50,25\% shading and full sunlight) $\mathrm{x} 2$ types of containers (plastic tubets and pots of plastic)] with four replicates of 10 seedlings each, thus totaling 240 seedlings. Means were compared by Tukey test, at $5 \%$ probability by using the software SISVAR 5.3 (Ferreira, 2011), and the adjustment of values of the polynomial linear regression curves was performed by using the SigmaPlot 11.0 software.

\section{Results AND Discussion}

Results have shown that interactions between the luminosity levels and seedling development were significant over time only to parameters stem diameter and root dry mass.

To parameter seedling stem diameter, the best results were obtained in the treatments where the seedlings were grown into plastic pots and kept under no-shaded conditions until the end of experiment (Figure 1A). The lowest values to this parameter were found in the treatment in which plants were grown into plastic tubets and grown under $25 \%$ shading. Nevertheless, to the plant height parameter, the best results were obtained at that same shading level (Figure 1B). However, when the seedlings were grown under full sunlight, or at the $50 \%$ shading level, they have had an intermediate development; but these results were not statistically different (Figure 1B).

In a study conducted with seedlings of the yellow Trumpet tree [Tabebuia aurea (Silva Manso) Benth \& Hook. Botelho (2011) has observed that the seedlings grew best when grown into rubberized pots, with $1.8 \mathrm{~L}$ of substrate than into plastic
A.
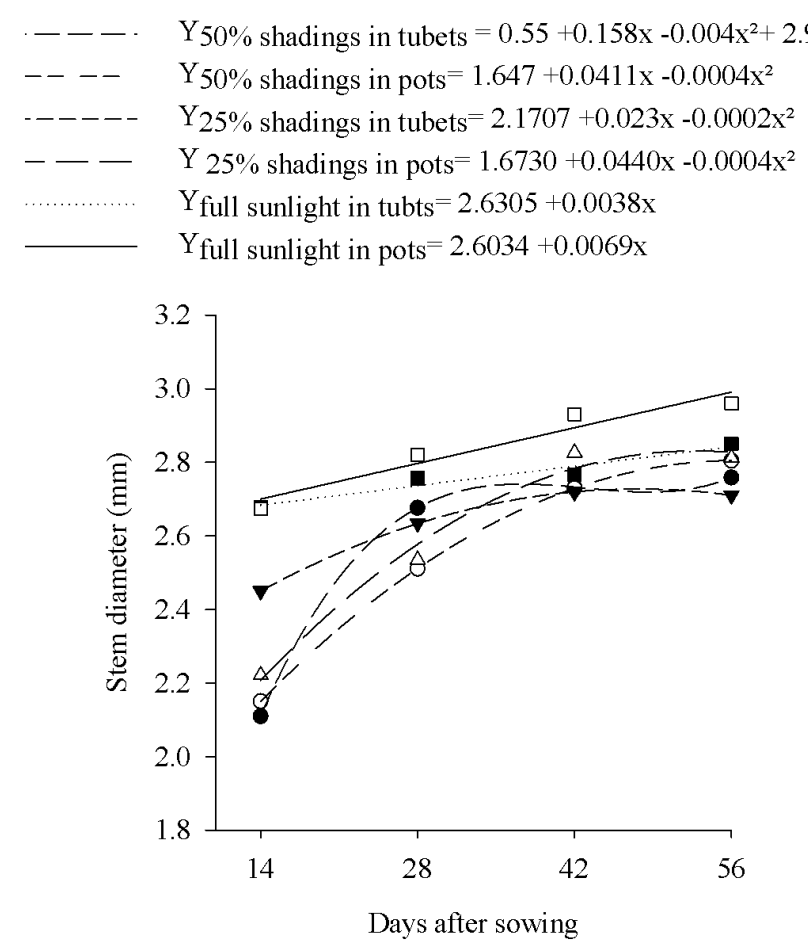

B.
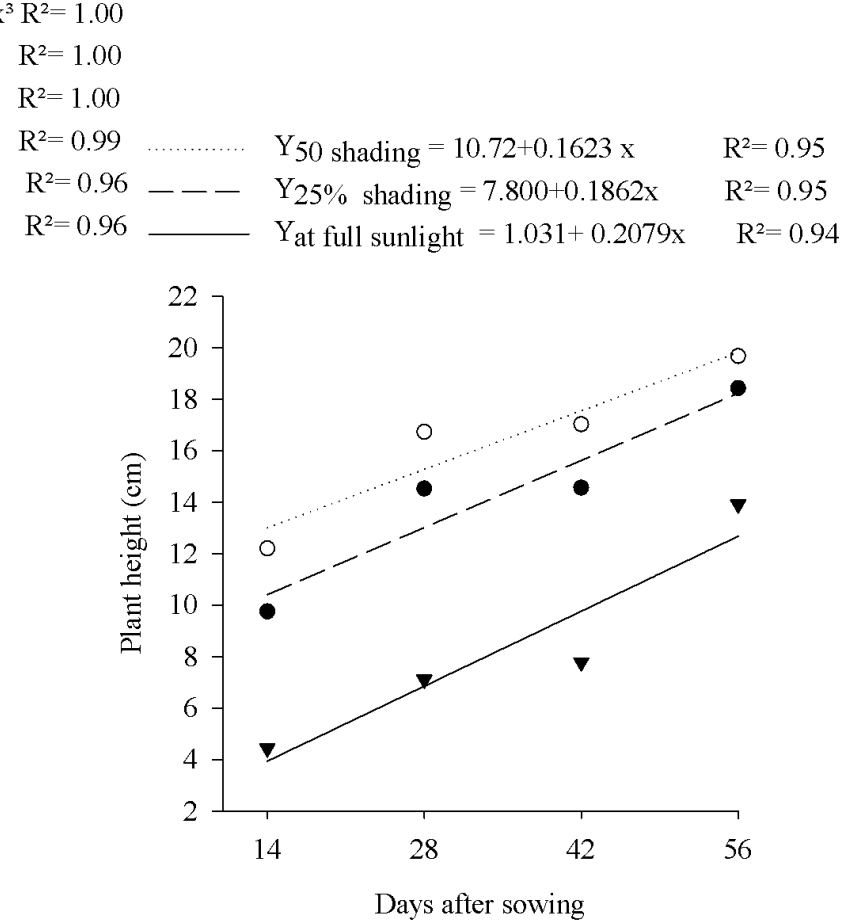

Figure 1. Graphical representation of the linear polynomial regression curves computed with mean results obtained to the parameters stem diameter (A) and plant height (B) of Cassia grandis seedlings, grown into two different types of containers and subjected to three different light intensity levels, and assessed every 14 days during a 56 days period 
tubets with $0.3 \mathrm{~L}$ of substrate. The author also emphasizes that this result was due to higher volume of substrate contained in the rubberized pots in relation to the substrate volume contained into the plastic tubets; thereby providing better conditions for development of seedlings of yellow Trumpet tree. Likewise, Cunha et al. (2005) working with seedlings of purple Trumpet tree [Tabebuia heptaphylla (Vell.) Toledo] have observed higher values to the stem diameter on the seedlings grown into containers with larger volume of substrate; emphasizing that seedlings grown into containers with a smaller volume of substrate may have their growth rate reduced, and consequently their production cycle increased.

Working with cedar [Cryptomeria japonica (L. fil.)], Santos et al. (2000) have also verified that seedlings grown into plastic tubets containing different substrate volumes, had larger stem diameter when they were grown into tubets with larger volume of substrate, than the seedlings grown into tubets with a smaller volume of substrate; which highlights that the capacity of container is more important than the type of container to be used to produce seedlings of this plant species. According to this author, the type of container to be used for seedlings will depend only on two factors: the easiness of its utilization by seedling producers; and of their storage conditions (easiness of stacking, durability, reuse possibility, cleaning easiness, etc.) of these containers.

Regarding effect of the luminosity levels, results obtained herein this study were similar to those results found by Carvalho Filho et al. (2002), who in studies performed with C. grandis seedlings has also verified, that, when grown under full sunlight, the seedlings have had higher mean values to the stem diameter than the seedlings grown under $50 \%$ shading. The author also emphasizes that this behavior might be a strategy of the seedling to overcome the environmental adversities in which it was grown by increasing its stem diameter and decreasing its height.

Similarly, Aguiar et al. (2005) have reported that stem diameter of brazilwood (Caesalpinia echinata Lam.) seedlings has not presented statistically significant differences on results obtained for this parameter when the seedlings of this species were developed under full sunlight, or 20 and $40 \%$ shading; nevertheless, when grown under 60 or $80 \%$ shading, the seedlings have shown higher values for stem diameter; however these values were not statistically different between each other. These findings differ from what was observed in this study, in which the shading effect of 25 and $50 \%$ have induced development of C. grandis seedlings with values statistically similar to the stem diameter.

Similar results were also observed by Fonseca et al. (2002) who studying seedlings of Jamaican nettletree [Trema micrantha (L.) Blume], under different shading levels have found that the decrease of stem diameter was linear as a function of the shading period under which the seedlings were grown. Nevertheless, Câmara \& Endres (2008) by assessing seedlings of the hard wood tree "sabiá" (Mimosa caesalpiniaefolia Benth.) as well as seedlings of skunk tree (Sterculia foetida L.) have found the best results for stem diameter when the seedlings of these two plant species were grown under $50 \%$ luminosity.
Results obtained in this study for height of the C. grandis seedlings have also disagreed from some of the information found in the specific literature on the issue. For example, Carvalho Filho et al. (2002), in a study carried out with this plant species obtained higher values for seedling height when they were grown under 50\% shading. Likewise, in their studies with seedlings of "sabiá" and skunk tree, Câmara \& Endres (2008) have found higher values to seedling height of those two plant species by using shading levels of 50 and $70 \%$. However, Campos \& Uchida (2002) have reported that 70\% shading was the most suitable for development of the seedlings of "jacarandá copaia" [Jacaranda copaia Aubl. D. Don].

Still within this subject, Silva \& Dantas (2014) has verified that seedlings of "quixaba" [Sideroxylon obtusifolium (Roem. $\&$ Schult)], when grown under $25 \%$ shading have had a height of $4.63 \mathrm{~cm}$; and when grown under $75 \%$ shading, the seedlings have had $4.33 \mathrm{~cm}$ height. However, when grown under $75 \%$ shading, the seedlings have had $4.33 \mathrm{~cm}$ in height. However, differently, in other study performed with seedlings of kapok [Ceiba pentandra (L.) Gaertn.], assessed under four different shading levels (0, 30, 50 and 70\%), Pedroso \& Varela (1995) did not find significant statistical differences among the values obtained for plant height. Nonetheless, studying influence of different shading levels on seedlings of the tree Peacock flower fence (Adenanthera pavonina L.) Fanti \& Perez (2003) have found that the height of the seedlings grown under $60 \%$ shading was greater than the height of the seedlings grown under $30 \%$ shading.

The fact the results obtained in this study have shown that the highest values for seedling height have occurred on the seedlings grown under shaded environments indicate that the low solar radiation was the factor responsible by the increase on the seedlings height of $C$. grandis, because the seedlings of this plant species were not able to normally grow under shaded environment. According to Silva et al. (2010) this is a defense mechanism through which, by adjusting its metabolic rate, the seedling is able to grow even in the environment with low level of luminosity of its original habitat.

For the root dry mass parameter there was interaction between the factors containers $x$ luminosity; being the highest values found to the interaction between the factors plastic tubets x 50\% luminosity, and the lowest values obtained to interaction between the factors plastic tubets $\mathrm{x}$ full sunlight (Table 2).

In relation to containers used for producing C. grandis seedlings, results obtained in this study have shown that there was significant interaction between the three luminosity

Table 2. Mean results obtained to the parameter root dry mass (g plant ${ }^{-1}$ ) of Cassia grandis seedlings grown into two different container types, and developed under three different luminosity levels

\begin{tabular}{ccc}
\hline Luminosity & \multicolumn{2}{c}{ Container type } \\
\cline { 2 - 3 } level & Plastic tubet & Plastic pot \\
$50 \%$ & $3.12 \mathrm{aA}$ & $2.68 \mathrm{aA}$ \\
$25 \%$ & $2.40 \mathrm{bA}$ & $2.44 \mathrm{aA}$ \\
Full sunlight & $1.34 \mathrm{cB}$ & $2.06 \mathrm{aA}$ \\
CV & \multicolumn{3}{c}{$16.24 \%$} \\
\hline
\end{tabular}

Means followed by the same lowercase letter in the column, and uppercase letter in the line do not statically differ between each other by Tukey test, at 0.05 probability 
levels and the two container types assessed. However, the mean values obtained to seedlings produced into the containers with larger volume of substrate (pots), and kept under full sunlight was lower than mean values obtained to the seedlings grown into the containers with smaller volume of the same substrate (tubets) and kept under the luminosity levels of 50 and $25 \%$. Nevertheless, the highest mean value was obtained to seedlings grown into plastic tubets and kept under the 50\% luminosity level. This should have occurred probably because the tubets, despite containing lower volume of substrate have provided better conditions for development of C. grandis seedlings with higher accumulation of biomass for being a container taller than the pots. Similar results were found by Carvalho Filho et al. (2002), who working with seedlings of the same plant species has obtained the highest values for dry weight of roots when the seedlings were grown under $50 \%$ shading into plastic bags $(15 \times 20 \mathrm{~cm})$. In their study with seedlings of Skunk tree and "sabiá", Câmara \& Endres (2008) have obtained the best results for the root dry mass on the seedlings grown under $50 \%$ shading; results that are similar to results obtained herein this study. However, Caron et al. (2010), by studying the influence of shading levels of 0, 30, 50 and $70 \%$ on seedlings of Brazilian Fern Tree [Schizolobium parahyba (Vell.) S. F. Blake] have found that these shading conditions did not affect the dry mass accumulation in the different organs of the assessed seedlings. Such results show that each plant species should be better studied, since regarding shading level each plant species has specific requirements to allow for an adequate development of their seedlings.

The mean values of total dry mass of stems and leaves, obtained for the seedlings grown under the luminosity levels of 25 and $50 \%$ did not statistically differ between each other; but were always higher than the mean values obtained for the seedlings grown under full sunlight (Table 3).

In similar work Azevedo et al. (2010), working with Simarouba amara Aubl. obtained the best medium to dry mass of shoot in shading of 30 and $50 \%$. According to these same authors, this low level of luminosity simulates a clearing under the canopy of larger trees under which the seedlings develop. Thereby, seedlings of this species have a natural trend of producing higher amounts of biomass in the shoots. Likewise, Almeida et al. (2005), by working on seedlings of "carobinha" (Jacaranda puberula Cham.) grown under 50\% shading have also found that such luminosity level has induced a higher

Table 3. Mean values obtained to stem dry mass, leaf dry mass, and total dry mass, as well as leaf area, ratio between plant height/stem diameter, and Dickson quality index, of Cassia grandis seedlings grown under three different luminosity levels

\begin{tabular}{|c|c|c|c|c|c|c|}
\hline \multirow{2}{*}{$\begin{array}{c}\text { Luminosity } \\
\text { level }\end{array}$} & SDM & LDM & TDM & \multirow{2}{*}{$\begin{array}{c}\mathrm{LA} \\
\mathrm{mm}^{2}\end{array}$} & \multirow{2}{*}{$\mathrm{PH} / \mathrm{SD}$} & \multirow{2}{*}{ DQI } \\
\hline & \multicolumn{3}{|c|}{ g planta ${ }^{-1}$} & & & \\
\hline $50 \%$ & 0.76 & $1.29 \mathrm{a}$ & $2.06 \mathrm{a}$ & $9765.31 b$ & & $1.81 \mathrm{a}$ \\
\hline $25 \%$ & $0.76 \mathrm{a}$ & $1.26 \mathrm{a}$ & 2.0 & $.21 \mathrm{a}$ & $5.20 \mathrm{a}$ & $1.70 \mathrm{a}$ \\
\hline Full sunlig & $0.32 \mathrm{~b}$ & $0.63 \mathrm{c}$ & $0.96 \mathrm{~b}$ & $3602.66 \mathrm{c}$ & $3.11 \mathrm{C}$ & $1.45 \mathrm{C}$ \\
\hline CV & $15.83 \%$ & $13.20 \%$ & $13.53 \%$ & $11.53 \%$ & $8.50 \%$ & 10.82 \\
\hline
\end{tabular}

Means followed by the same lowercase letter in the column and uppercase letter on the line do not statistically differ between each other by Tukey test, at 0.05 probability; SDM - Stem dry mass; LDM - Leaf dry mass; TDM - Total dry mass; LA = leaf area; PH/SD = ratio between plant height/stem diameter; DQI = Dickson quality index accumulation of foliar dry mass. Moreover, according to Faria et al. (2002) seedlings presenting higher dry mass of leaves also have greater leaf area; since this characteristic, besides aiding the early seedling development by allowing higher sunlight capture, may also provide greater vigor to plants, due to higher photosynthetic rate of seedlings.

Similar results were also found by Câmara \& Endres (2008), who on the study performed with seedlings of Skunk tree and "sabiá" have obtained the best values for total dry mass in the seedlings grown under 50\% shading. However, Campos \& Uchida (2002) have found that in seedlings of "jacarandá copaia", when seedlings were grown under 30, 50, and $70 \%$ shading or full sunlight there was no statistically significant differences between the values obtained for the total dry mass. Similarly, Caron et al. (2010) have observed that "guapuruvu" seedlings showed no statistically significant difference between the values obtained to such variable. The largest dry mass accumulation by the $C$. grandis seedlings assessed herein this study was probably a consequence of a better ecological adaptation of such plant species in conserving more energy to be able to grow properly in the areas with low luminosity occurring in their original habitat.

According to Mota et al. (2012), the highest values of leaf area observed in shaded environments are related to a plant morphological feature aiming at maximizing interception of sunlight; what agrees with results found by Silva et al. (2004), who by working with butterfly pea tree (Clitoria fairchildinana R. A. Howard) seedlings, grown under shading of 70 and $50 \%$, and at full sunlight, have found that the highest values for leaf area of seedlings assessed occurred in the cultivation environment with $50 \%$ shading. However, in a study carried out with Dragon's blood (Croton urucurana Baill.) seedlings, Alvarenga et al. (2003) have obtained the highest values for leaf area when the seedlings were grown under $70 \%$ shading. These results confirm that, depending on shading level there is a proportional increase in the seedling leaf area. This morphological feature was also demonstrated in this study, since to the dry leaf mass of the C. grandis seedlings assessed, the highest values were obtained in the seedlings grown under shadings of 25 and $50 \%$, in relation to seedlings grown under full sunlight.

Similarly, Câmara \& Endres (2008), in their study with seedlings of Skunk tree and "sabiá" obtained the highest values to the ratio between plant height/stem diameter, when these seedlings were grown under 50 or $70 \%$ shading. However, by working with seedlings of "Caroba" (Jacaranda copaiba L.), "jatobá" (Hymenaea courbaril L.), and boat tree (Ochroma lagopus Swartz), Campos \& Uchida (2002) have found, that when the seedlings were grown under $70 \%$ shading, the values for the ratio between plant height/stem diameter, of those three plant species seedlings were higher than those values observed for the seedlings grown under lower shading levels.

However, the positive influence of shading on seedling quality of forest species has already been reported by Chaves \& Paiva (2004), who working with seedlings of velvet-leaf senna [Senna macranthera (DC. ex Collad.)] observed that Dickson quality index was higher when the seedlings have remained 105 days under shading. Although, in a study with seedlings of 
"paricá" (Schizolobium amazonicum Huber ex Ducke), Rosa et al. (2009) have found that seedlings grown under 30\% shading have had the values for Dickson quality index higher than that of the seedlings grown under 50 or $70 \%$ shading. According to Moraes Neto et al. (2000), development of forest species seedlings under shaded environments is a plant strategy to be able to survive under low luminosity conditions. Nevertheless, on the C. grandis seedlings assessed herein this study, the highest mean for the DQI were found for the seedlings grown under $50 \%$ shading.

Results obtained herein this study have made clear, that despite all luminosity levels were adequate for producing $C$. grandis seedlings (DQI above 0.2), those grown under full sunlight had a high mortality rate. Besides, those seedlings that did not die have had a very slow development over all the 56 days assessment period. Hence, cultivation of C. grandis seedlings under full sunlight should not be recommended; since the seedlings assessed in this study under such luminosity level have had a very low development when assessed by the DQI.

\section{Conclusions}

1. For adequate production of seedlings of C. grandis, the seedling cultivation should be carried out in nurseries with 25 to $50 \%$ shading.

2. Seedlings of C. grandis have more suitable development when grown into plastic tubets.

\section{Literature Cited}

Aguiar, F. F. A.; Kanashiro S.; Tavares, A. R.; Pinto, M. M.; Stancato, G. C.; Aguiar, J.; Nascimento, T. D. R. Germinação de sementes e formação de mudas de Caesalpinia echinata Lam. (pau-brasil): efeito de sombreamento. Revista Árvore, v.29, p.871-875, 2005. http://dx.doi.org/10.1590/S0100-67622005000600005

Almeida, L. S.; Maia, N.; Ortega, A. R.; Angelo, A. C. Crescimento de mudas de jacaranda puberula Cham. em viveiro submetidas a diferentes níveis de luminosidade. Ciência Florestal, v.15, p.323329, 2005. http://dx.doi.org/10.5902/19805098

Alvarenga, A. A.; Castro, E. M.; Lima Júnior, E. C.; Magalhães, M. M. Effects of different light levels on the initial growth and photosynthesis of Croton urucurana Baill. in southeastern Brazil. Revista Árvore, v.27, p.53-57, 2003. http://dx.doi.org/10.1590/ S0100-67622003000100007

Azevedo, I. M. G.; Alencar, R. M.; Barbosa, A. R.; Almeida, N. O. Estudo do crescimento e qualidade de mudas de marupá (Simarouba amara Aubl.) em viveiro. Acta Amazônica, v.40, p.157164, 2010. http://dx.doi.org/10.1590/S0044-59672010000100020

Bezerra, F. T.C.; Andrade, A. L.; Bezerra, M. A. F.; Pereira, W. E. Fabricante, J. R.; Oliveira, L. S. B.; Feitosa, R. C. Biometria de frutos e sementes e tratamentos pré-germinativos em Cassia grandis L.f. (Fabaceae). Semina: Ciências Agrárias, v.33, p.2863-2876, 2012. http://dx.doi.org/10.5433/1679-0359.2012v33n6Supl1p2863

Botelho, A. V. F. Influência de substratos e recipientes na qualidade das mudas de Tabebuia aurea (Silva Manso) Benth. \& Hook. F. ex S. Moore. Recife: UFRPE, 2011. 60p. Dissertação Mestrado

Câmara, C. A.; Endres, L. Desenvolvimento de mudas de duas espécies arbóreas Mimosa caesalpiniifolia Benth. e Sterculia foetida L. sob diferentes níveis de sombreamento em viveiro. Floresta, v.38, p.43-51, 2008.
Campos, M. A. A.; Uchida, T. Influência do sombreamento no crescimento de mudas de três espécies amazônicas. Pesquisa Agropecuária Brasileira, v.37, p.281-288, 2002. http://dx.doi. org/10.1590/S0100-204X2002000300008

Caron, B. O.; Souza, V. Q.; Cantarelli, E. B.; Manfron, P. A.; Behling, A.; Eloy, E. Crescimento em viveiro de mudas de Schizolobium parahyba (Vell.) S. F. Blake. submetidas a níveis de sombreamento. Ciência Florestal, v.20, p.683-689, 2010. http:// dx.doi.org/10.5902/19805098

Carvalho Filho, J. L. S.; Arrigoni-Blank, M. F.; Blank, A. F.; Santos Neto, A. L.; Amâncio, V. F. Produção de mudas de Cassia grandis L. f. em diferentes ambientes, recipientes e misturas de substratos. Ceres, v.49, p.341-352, 2002.

Chaves, A. S.; Paiva, H. N. Influência de diferentes períodos de sombreamento sobre a qualidade de mudas de fedegoso (Senna macranthera (Collad.) Irwin et Barn.). Scientia Forestalis, v.65, p.22-29, 2004.

Cunha, A. O.; Andrade, L. A.; Bruno, L. R. A.; Silva, J. A. L.; Sousa, V. C. Efeito dos substratos e das dimensões dos recipientes da qualidade de mudas de Tabebuia impetiginosa (Mart. Ex. D. C.) Standl. Revista Árvore, v.29, p.511-514, 2005. http://dx.doi. org/10.1590/S0100-67622005000400002

Dickson, A.; Leaf, A. L.; Hosner, J. F. Quality appraisal of white spruce and white pine seedling stock in nurseries. Forest Chronicle, v.36. p.10-13, 1960.

Fanti, S. C.; Perez, S. C. J. G. A. Influência do sombreamento artificial e da adubação química na produção de mudas de Adenanthera pavonina. Ciência Florestal, v.13, p.49-56, 2003. http://dx.doi. org/10.5902/19805098

Faria, W. S. de; Gaiva, I. X.; Pereira, W. E. Comportamento de cinco genótipos de coqueiro (Cocos nucifera L.) na fase de germinação e de crescimento de mudas, sob diferentes sistemas de produção. Revista Brasileira de Fruticultura, v.24, p.458-462, 2002. http:// dx.doi.org/10.1590/S0100-29452002000200035

Ferreira, D. F. Sisvar: A computer statistical analysis system. Ciência e Agrotecnologia, v.35, p.1039-1042, 2011. http://dx.doi. org/10.1590/S1413-70542011000600001

Fonseca, E. P.; Valéri, S. V.; Miglioranza, E.; Fonseca, N. A. N.; Couto, L. Padrão de qualidade de mudas de Trema micrantha (L.) Blume, produzidas sob diferentes períodos de sombreamento. Revista Árvore, v.26, p.515-523, 2002. http://dx.doi.org/10.1590/S010067622002000400015

Lodha, S. R.; Joshi, S. V.; Vyas, B. A.; Kirve, M. S.; Salunke, S. S.; Kadu, S. K.; Rogye, M. V. Assessment of the antidiabetic potential of Cassia grandis using an in vivo model. Journal of Advanced Pharmaceutical Technology \& Research, v.1. p.330-333, 2010. http://dx.doi.org/10.4103/0110-5558.72429

Lorenzi, H. Árvores brasileiras: Manual e cultivo de plantas arbóreas nativas do Brasil. Nova Odessa: Plantarum, 2002. 352p.

Martins, C. C.; Silva, J. D. R.; Pereira, M. R. R.; Oliveira, S. S. C. Efeito do sombreamento e do substrato sobre a germinação e o crescimento de plântulas de Acacia mangium e Acacia mearnsii. Ciência Florestal, v.22, p.283-293, 2012. http://de.doi. org/10.5902/19805098

Moraes Neto, S. P.; Gonçalves, J. L. M.; Takaki, M.; Cenci, S.; Gonçalves, J. C. Crescimento de mudas de algumas espécies arbóreas que ocorrem na mata atlântica, em função do nível de luminosidade. Revista Árvore, v.24, p.35-45, 2000. 
Mota, L. H. S.; Scalon, S. P. Q.; Heinz, R. Sombreamento na emergência de plântulas e no crescimento inicial de Dipteryx alata vog. Ciência Florestal, v.22, p.423-431, 2012.http://dx.doi.org/10.5902/19805098

Oliveira, A. K. M.; Perez, S. C. J. G. A. Crescimento inicial de tabebuia aurea sob três intensidades luminosas. Ciência Florestal, v.22, p.263-273, 2012. http://dx.doi.org/10.5902/198050985733

Oliveira, L. S. B.; Andrade, L. A.; Alves, A. S.; Gonçalves, G. S. Substrato e volume de recipiente na produção de mudas de jatobá (Hymenaea courbaril L.). Nativa, v.2, p.103-107, 2014. http:// dx.doi.org/10.14583/2318-7670.v02n02a07

Pedroso, S. G., Varela, V. P. Efeito do sombreamento no crescimento de mudas de Sumaúma (Ceiba pentandra (L.) Gaertn). Revista Brasileira de Sementes, v.17, p.47-51, 1995.

Rosa, L. S.; Vieira, T. A.; Santos, D. S.; Silva, L. C. B. Emergência, crescimento e padrão de qualidade de mudas de Schizolobium amazonicum Huber ex Ducke sob diferentes níveis de sombreamento e profundidades de semeadura. Revista Ciências Agrárias, v.52, p.87-98, 2009.
Santos, C. B.; Longhi, S. J.; Hoppe, J. M.; Moscovich, A. F. Efeito do volume de tubetes e tipos se substratos na qualidade de mudas de Cryptomeria japonica (L.F) D. Dom. Ciência Florestal, v.10, p.1-15, 2000. http://dx.doi.org/10.5902/19805098

Silva, A. S.; Oliveira, J. G.; Cunha, M.; Vitória, A. P. Photosynthetic performance and anatomical adaptations in Byrsonima sericea DC. under contrasting light conditions in a remnant of the Atlantic forest. Brazilian Journal of Plant Physiology, v.22, p.245-254, 2010. http://dx.doi.org/10.1590/S1677-04202010000400004

Silva, B. M. S.; Cesarino, F.; Pantoja, T. F. Efeito de diferentes níveis de radiação sobre o crescimento inicial de Clitoria fairchildinana R. A. Howard. In: Reunião Anual do Instituto Biológico, 17, 2004, São Paulo. Anais... São Paulo: Instituto Biológico, 2004. v.71, p.1-749.

Silva, F. F. S.; Dantas, B. F. Taxas de crescimento de mudas de quixabeira submetidas a diferentes condições de sombreamento e tipos de substratos. Scientia Plena, v.10, p.1-7, 2014. 